Article

\title{
Epoxidation of Karanja (Millettia pinnata) Oil Methyl Esters in the Presence of Hydrogen Peroxide over a Simple Niobium-Containing Catalyst
}

\author{
Nicola Scotti ${ }^{1}$, Nicoletta Ravasio ${ }^{1}{ }^{\circledR}$, Claudio Evangelisti $^{1}{ }^{\circledR}$, Rinaldo Psaro ${ }^{1}$, Michele Penso ${ }^{1}$, \\ Prashant S. Niphadkar ${ }^{2}$, Vijay V. Bokade ${ }^{2}$ and Matteo Guidotti ${ }^{1, *(1)}$ \\ 1 CNR_Istituto di Scienze e Tecnologie Molecolari, 20133 Milano, Italy; nicola.scotti@istm.cnr.it (N.S.); \\ nicoletta.ravasio@istm.cnr.it (N.R.); claudio.evangelisti@istm.cnr.it (C.E.); r.psaro@istm.cnr.it (R.P.); \\ michele.penso@istm.cnr.it (M.P.) \\ 2 CSIR—National Chemical Laboratory, Pune 411008, India; pniphadkar@gmail.com (P.S.N.); \\ vv.bokade@ncl.res.in (V.V.B.) \\ * Correspondence: m.guidotti@istm.cnr.it; Tel.: +39-02-5031-4428
}

Received: 21 February 2019; Accepted: 3 April 2019; Published: 8 April 2019

\begin{abstract}
The synthesis, characterization and catalytic performance of a conceptually simple, novel $\mathrm{NbO}_{\mathrm{x}}-\mathrm{SiO}_{2}$ catalyst are here described. The niobium(V)-silica catalyst was prepared starting from cheap and viable reactants, by alkaline deposition of $\mathrm{NH}_{4} \mathrm{Nb}\left(\mathrm{C}_{2} \mathrm{O}_{4}\right)_{2} \cdot \mathrm{H}_{2} \mathrm{O}$ in the presence of fructose as a stabilizer and subsequent calcination. The $\mathrm{NbO}_{\mathrm{x}}-\mathrm{SiO}_{2}$ solid $(0.95 \mathrm{Nb}$ wt.\%) was tested in the liquid-phase epoxidation with aqueous hydrogen peroxide of methyl oleate, as a model substrate. It was then tested in the epoxidation of a mixture of methyl esters (FAMEs) obtained by transesterification with methanol and purification of karanja oil, extracted from the autochthonous Indian variety of Millettia pinnata tree. The catalyst showed a promising performance in terms of methyl oleate conversion (up to $75 \%$ ) and selectivity to epoxide (up to $82 \%$ ). It was then tested on the FAME mixture from karanja oil, where interesting conversion values were attained (up to 70\%), although with lower selectivities and yields to the mixture of desired epoxidized FAMEs. The solid withstood four catalytic cycles overall, during which a non-negligible surface reorganization of the $\mathrm{Nb}(\mathrm{V})$ sites was observed. However, this restructuring did not negatively affect the performance of the catalysts in terms of conversion or selectivity.
\end{abstract}

Keywords: heterogeneous catalysis; epoxidation; niobium catalysts; karanja oil; fatty acid methyl esters; hydrogen peroxide; Millettia pinnata; mesoporous silica catalyst

\section{Introduction}

Epoxide derivatives of fatty acid methyl esters (FAMEs) proved to be among the most versatile intermediates in oleochemistry, as they can be easily transformed into a broad series of key products through oxirane ring opening [1-3]. Triacylglycerols, obtained not only from vegetable origin, but also from animal sources, in fact, represent one of the cheapest and most available starting materials for replacing petroleum-derived products. Their derivatives found successful application in niche domains, such as lubricants for total-loss applications $[4,5]$, plastifying agents for food-grade products $[6,7]$ or intermediates for pharmaceutical uses [8,9]. However, in order to attain an appropriate degree of sustainability of the overall process and to properly tackle the fuel vs. food/feed biomass dilemma, the scientific community is paying an ever-increasing attention to oleochemicals derived from either non-edible oils, extracted from land- or water-saving crops, or animal fats, obtained from food-processing waste [10-12]. In this scenario, India possesses a broad variety of non-edible oil-bearing vegetable sources, such as jatropha (Jatropha curcas), neem (Azadirachta indica), mahua (Madhuca longifolia), castor (Ricinus 
communis) and, in particular, karanja (Millettia pinnata). Triacylglycerols extracted from these species feature a high percentage of unsaturated fatty acids, which can be easily functionalised and converted into high added-values intermediates [10,13].

Karanja, also known as Indian beech, is a medium-sized fast-to-grow tree, that can easily withstand heat, drought, salinity and frost conditions. It can also reclaim marginal lands and, in many cases, its seeds, which contain 27 to $39 \%$ of fat with yearly oil yields as high as $2.0-4.0 \mathrm{t} / \mathrm{ha}$, often remain unused [14]. It has therefore a potential to be used as an alternative feedstock for the production of oleochemicals. Nonetheless, a modest number of studies is present in the current state-of-the-art dealing with the transformation of karanja-derived FAMEs [15-24], other than the production of biodiesel fuels. More specifically, to our best knowledge, only one report has explored the use of a heterogeneous catalyst $\left(\mathrm{Ti} / \mathrm{SiO}_{2}\right)$ for the epoxidation of Millettia pinnata oil FAMEs so far, but, in this case, the co-presence of either formic acid or UV irradiation was necessary to successfully carry out the epoxidation reaction [18].

Since the final goal of the present study is to explore the possibility of converting unsaturated FAMEs obtained from karanja oil following an environmentally and economically sustainable approach, we focused our attention onto the use of aqueous hydrogen peroxide, as an oxidant, in the presence of a simple heterogeneous catalyst. For this reason, we moved from titanium(IV)-silica catalysts, that are deeply-studied, although less robust and prone to deactivation when in contact with water-containing media [25-28], towards niobium(V)-silica systems, which showed promising features in terms of activity, selectivity to epoxides and robustness, also in the presence of aqueous $\mathrm{H}_{2} \mathrm{O}_{2}$ [29-35]. Niobium(V)-containing mesoporous silica catalysts in epoxidation reactions, indeed, comply with the main guidelines of Green and Sustainable Chemistry: they do not require hazardous corrosive reactants, avoiding the use of peroxoacids; they circumvent tedious separation and recovery techniques, thanks to their heterogeneous nature, and, by exploiting the oxidizing properties of hydrogen peroxide, only water and dioxygen, in the case of its decomposition, are formed [36-38]. Moreover, niobium-silica catalysts displaying a network of mesopores, either ordered or non-ordered, proved to be suitable solid catalysts where the epoxidation of bulky vegetable oil FAMEs can be carried out, thanks to the easy steric accessibility of their mesoporous channels to substrate molecules [39-43].

Therefore, the present report aims at investigating the performance of a conceptually simple, but unexplored niobium oxide on silica catalyst, $\mathrm{NbO}_{x}-\mathrm{SiO}_{2}$, obtained from cheap and viable precursors, via a novel deposition procedure, that follows a similar experimental approach previously adopted for copper-oxide catalysts [44]. The niobium-silica catalyst was then tested in the liquid-phase epoxidation with aqueous hydrogen peroxide, not only of methyl oleate (Me-OLE), as a model substrate, but also of the mixture of fatty acid methyl esters obtained by transesterification of karanja tree oil. This novel catalyst was thus tested in the transformation of a FAME mixture derived from a scarcely studied vegetable raw material.

\section{Results and Discussion}

\subsection{Preparation and Characterization of Karanja Oil FAME Mixture}

Karanja FAME mixture was obtained by esterification with sodium methoxide and subsequent distillation under vacuum, according to an approach previously used with vegetable oils of different origin [45]. Thanks to the limited free acidity of the crude karanja oil $\left(4.36 \mathrm{mg} \mathrm{KOH} \mathrm{g}^{-1}\right)$ with respect to most of non-edible oils from vegetable origin, a methoxide-mediated transesterification could be used instead of an acid-catalyzed one [46]. The raw FAME mixture then underwent distillation under vacuum in order to remove most of the non-lipidic compounds, such as gums, volatile or heavy/odorous components, that might be present and negatively affect the catalytic reactivity, by catalyst fouling.

Karanja FAME mixture contained a remarkable fraction of unsaturated esters: 51.6, 17.7, 0.7, $0.8 \mathrm{~mol} \%$ for $\mathrm{C} 18: 1, \mathrm{C} 18: 2$ and $\mathrm{C} 20: 1$ and C22:1, respectively (Table 1 ). These $\mathrm{C}=\mathrm{C}$ bonds accounted for a total iodine value of 99.8 , which is fully comparable to the values reported in previous reports $[18,47]$. The FAME mixture was also characterized by ${ }^{1} \mathrm{H}$ and ${ }^{13} \mathrm{C}$ NMR spectroscopy (Figure S1 and S2). 
Table 1. Lipidic composition of the karanja fatty acid methyl esters (FAME) mixture used in the present study.

\begin{tabular}{cc}
\hline FAME & Content (mol\%) \\
\hline C16:0 & 11.7 \\
C18:0 & 6.3 \\
C18:1 & 51.6 \\
C18:2 & 17.7 \\
C20:0 & 0.8 \\
C20:1 & 0.7 \\
C22:0 & $10.1^{*}$ \\
C22:1 & 0.8 \\
other minor & 0.3 \\
\hline * with minor amounts of C18:3.
\end{tabular}

\subsection{Preparation of the $\mathrm{NbO}_{x}-\mathrm{SiO}_{2}$ Catalyst}

The $\mathrm{NbO}_{\mathrm{x}}-\mathrm{SiO}_{2}$ catalyst was prepared by dissolving the desired amount of $\mathrm{NH}_{4} \mathrm{Nb}\left(\mathrm{C}_{2} \mathrm{O}_{4}\right)_{2} \cdot \mathrm{H}_{2} \mathrm{O}$ precursor in water, at alkaline $\mathrm{pH}$, in the presence of fructose, as a stabilizer. A niobium to fructose molar ratio of 1:5 allowed us to have a proper dissolution of the precursor, avoiding the parallel undesired precipitation of oxo-hydroxo species of niobium $(\mathrm{V})$, that occurs when the sugar is not present. Even if it was not possible to get a clear evidence of the formation of a niobium-fructose complex and of its possible composition, we could reasonably draw a parallel with some monosaccharide-metal adducts that were already synthesized in the presence vanadium precursors and monosaccharides as chelating agents $[48,49]$. The addition of the high surface area silica support and the dropwise addition of water promote the deposition of the $\mathrm{Nb}$ species onto silica. After a thorough filtration, that removes the excess of fructose-niobium adduct that was not strongly bound to the oxidic support, the calcination step in air gave rise to the final white $\mathrm{NbO}_{x}-\mathrm{SiO}_{2}$ solid.

It is worth highlighting that such a preparation approach is conceptually simpler and more affordable, in terms of economic resources, than other synthesis routes reported so far $[31,32,50]$. Indeed, the preparation steps required no operations under inert or controlled atmosphere, no costly and/or hazardous precursors and no organic solvents ( $c f$. the different synthesis procedure, described in Section 3.2, for a benchmark Nb-MCM-41 catalyst, here used for comparison).

\subsection{Characterization of the $\mathrm{NbO}_{x}-\mathrm{SiO}_{2}$ Catalyst}

The niobium content in the $\mathrm{NbO}_{x}-\mathrm{SiO}_{2}$ catalyst was checked by digestion plus ICP-AES elemental analysis. A metal loading of $0.95 \mathrm{wt} . \%$ was recorded, although the expected $\mathrm{Nb}$ content, according to the starting synthesis mixture, was ca. $3 \mathrm{wt} . \%$. Such difference suggests that the deposition procedure was not quantitative and approximately two thirds of the $\mathrm{Nb}$ species contained in the precursor salt were filtered out from the solid support during the filtration step. Nevertheless, since a uniform dispersion of the catalytically active $\mathrm{Nb}(\mathrm{V})$ sites over the silica is a sought-after feature for this kind of heterogeneous oxidation catalysts, the dispersion of the metal centers and the chemical environment surrounding the $\mathrm{Nb}(\mathrm{V})$ atoms were studied by diffuse reflectance UV-vis spectroscopy, DRS UV-vis, (Figure 1), X-ray diffraction (Figure S3) and HAADF-STEM microscopy with Energy Dispersive X-ray Spectrometry, EDS, mapping across the grains (Figure 2).

The $\mathrm{NbO}_{x}-\mathrm{SiO}_{2}$ catalyst showed a rather narrow $\mathrm{UV}$ absorption band centered around $225-235 \mathrm{~nm}$, due to the ligand to metal charge-transfer transitions between oxygen atoms and $\mathrm{Nb}(\mathrm{V})$ sites in tetrahedral coordination [31]. This means that most of the metal $\mathrm{Nb}(\mathrm{V})$ centers were isolated and evenly dispersed on the silica surface. Actually, the absence of absorption features at wavelength values higher than $300-310 \mathrm{~nm}$ suggests that no $\mathrm{Nb}$ centers in isolated penta- or hexa-coordinated geometry were present [41,51]. The occurrence of larger niobia-like domains can be excluded as well [52]. In fact, by comparing the spectrum of the $\mathrm{NbO}_{\mathrm{x}}-\mathrm{SiO}_{2}$ sample and the one of a bulk reference $\mathrm{Nb}_{2} \mathrm{O}_{5}$ solid, 
no bands were detected between 300 and $400 \mathrm{~nm}$ for the former, whereas a broad absorption was evident for the latter (Figure 1, spectrum $b$ vs. spectrum a).

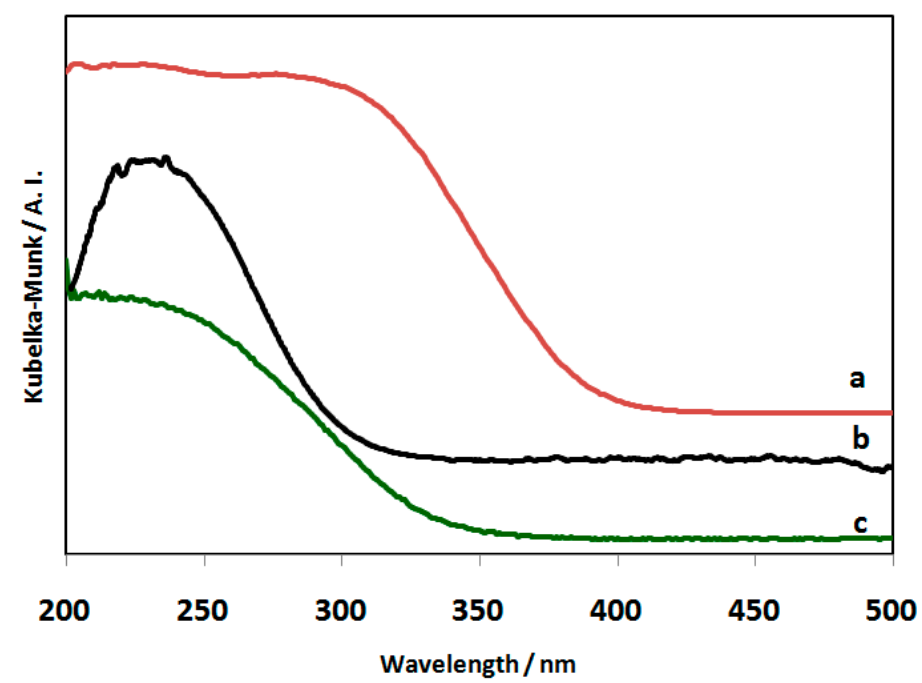

Figure 1. DRS UV-vis pattern of: reference bulk $\mathrm{Nb}_{2} \mathrm{O}_{5}$ solid (a); freshly calcined $\mathrm{NbO}_{\mathrm{x}}-\mathrm{SiO}_{2}$ catalyst (b); and $\mathrm{NbO}_{\mathrm{x}}-\mathrm{SiO}_{2}$ catalyst after four catalytic cycles and calcination at $500{ }^{\circ} \mathrm{C}$ under dry air (c).
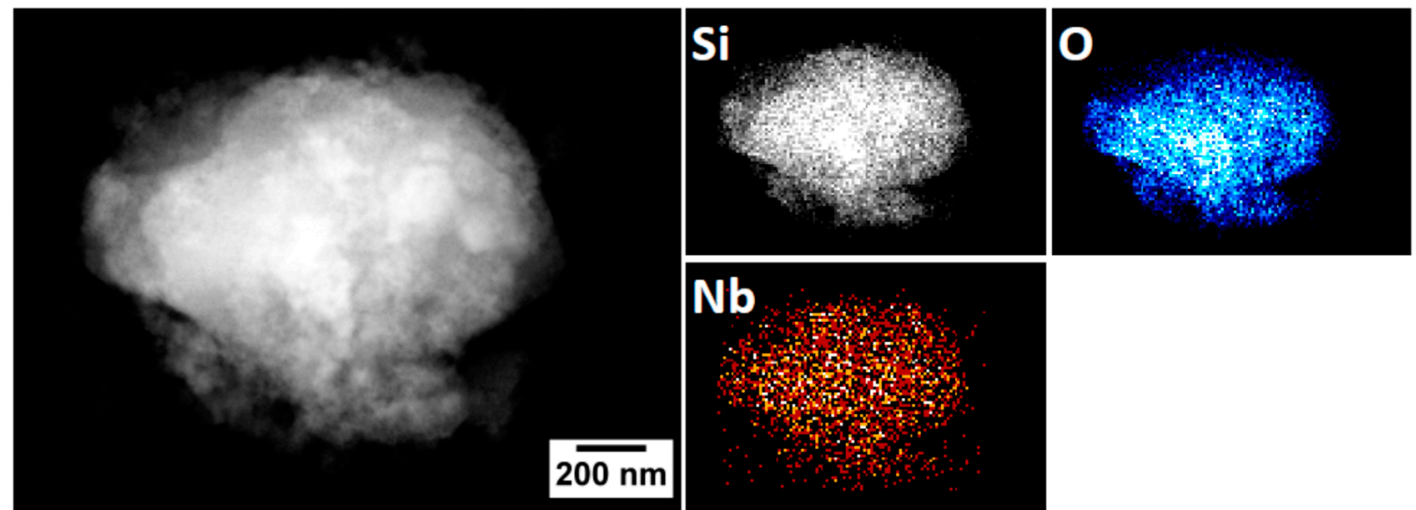

Figure 2. Representative HAADF-STEM micrograph of a $\mathrm{NbO}_{x}-\mathrm{SiO}_{2}$ grain and corresponding EDS element mapping.

$\mathrm{NbO}_{\mathrm{x}}-\mathrm{SiO}_{2}$ was also studied by $\mathrm{XRD}$ spectroscopy (Figure S3). The silica support is fully amorphous and only a very broad absorption band is observed around $20-25^{\circ} 2$ theta values. No specific XRD peaks of crystalline phases of $\mathrm{Nb}_{2} \mathrm{O}_{5}$ (or niobia-like domains) were detected. Typically, $\mathrm{Nb}_{2} \mathrm{O}_{5}$ nanoparticles with orthorhombic symmetry display reflections around $22.7^{\circ}, 28.6^{\circ}$ and $36.9^{\circ}$ [53]. The absence of this kind of peaks is fully consistent with the DRS-UV-vis investigation (Figure 1), where the presence of $\mathrm{Nb}_{2} \mathrm{O}_{5}$ crystalline aggregates would have been evidenced by such very sensitive technique.

High resolution transmission electron micrographs excluded the presence of segregated $\mathrm{NbO}_{x}$ phases (Figure S4), in agreement with the data reported above. EDS element mapping on a representative HAADF-STEM micrograph revealed a high dispersion of niobium atoms over the catalyst grains (Figure 2). The $\mathrm{Nb}$ loading calculated from the resulting EDS spectrum (Figure S5, Nb $=0.91 \mathrm{wt} . \%$ ) resulted very similar to the one revealed by ICP-AES analysis $(\mathrm{Nb}=0.95 \mathrm{wt} . \%)$.

The textural analysis of the $\mathrm{NbO}_{x}-\mathrm{SiO}_{2}$ catalyst showed that the deposition of the niobium species did not remarkably affect the original pore structure of the support (Table 2 and Figure S6). A small decrease in specific surface area and total pore volume were observed with respect to the pristine silica, thus confirming that no large oxidic aggregates plugged or blocked the pore network, in full agreement 
with the DR-UV, XRD and HAADF-STEM investigations. All experimental techniques showed that the sugar-assisted deposition approach led to a uniform dispersion of $\mathrm{Nb}$ sites over the silica support, with a very low surface density of $\mathrm{Nb}$ species, of ca. $0.15 \mathrm{Nb}$ atoms per square nanometer. Such surface metal density is consistent with previous reports in which $\mathrm{NbO}_{x}-\mathrm{SiO}_{2}$ catalysts, although obtained via more complicated synthesis pathways or sensitive precursors [27,32,41], displayed a good performance in the epoxidation of alkenes.

Table 2. Textural features of the original $\mathrm{SiO}_{2}$ support and $\mathrm{NbO}_{\mathrm{x}}-\mathrm{SiO}_{2}$ catalyst.

\begin{tabular}{cccc}
\hline Sample & $\left.\mathbf{S S A}^{\mathbf{a}} \mathbf{( m}^{\mathbf{2}} \mathbf{g}^{\mathbf{- 1}}\right)$ & $\mathbf{P V}^{\mathbf{b}}\left(\mathbf{m L ~}^{\mathbf{- 1}}\right)$ & $\mathbf{P D}_{\max }{ }^{\mathbf{c}}(\mathbf{n m})$ \\
\hline $\mathrm{SiO}_{2}$ & 460 & 0.74 & 5.7 \\
$\mathrm{NbO}_{\mathbf{x}}-\mathrm{SiO}_{2}$ & 404 & 0.70 & 6.0
\end{tabular}

a: specific surface area (from BET analysis); b: total pore volume; c: BJH pore distribution maximum (see also Figure S5).

Since the epoxidation of alkenes over niobium-silica catalysts generally takes place on $\mathrm{Nb}(\mathrm{V})$ sites that promote the oxygen transfer from the oxidant to the $\mathrm{C}=\mathrm{C}$ bond $[29,54,55]$, the acidity of $\mathrm{NbO}_{x}-\mathrm{SiO}_{2}$ was investigated by means of pyridine adsorption/desorption tests. The corresponding spectra showed the presence of bands in the range of $1400-1700 \mathrm{~cm}^{-1}$ (Figure 3). Physisorbed pyridine with a very weak interaction with the surface resulted in a band at $1440-1445 \mathrm{~cm}^{-1}$ and a second one at $1580-1600 \mathrm{~cm}^{-1}$ which rapidly decreased with the temperature until a complete disappearance at $100{ }^{\circ} \mathrm{C}$. On the other hand, pyridine lying on Lewis acid sites accounted for bands around $1450 \mathrm{~cm}^{-1}$ and $1610 \mathrm{~cm}^{-1}$ that were resistant to outgassing and could be still detected at $250{ }^{\circ} \mathrm{C}$, even with a reduced intensity. Brønsted acid sites generally give rise to an absorption at $1550 \mathrm{~cm}^{-1}$, followed by a peak near $1640 \mathrm{~cm}^{-1}$, but, in this case, they were totally absent. The $\mathrm{NbO}_{x}-\mathrm{SiO}_{2}$ catalyst thus showed only a Lewis acid character, whereas no Brønsted sites were clearly detected.

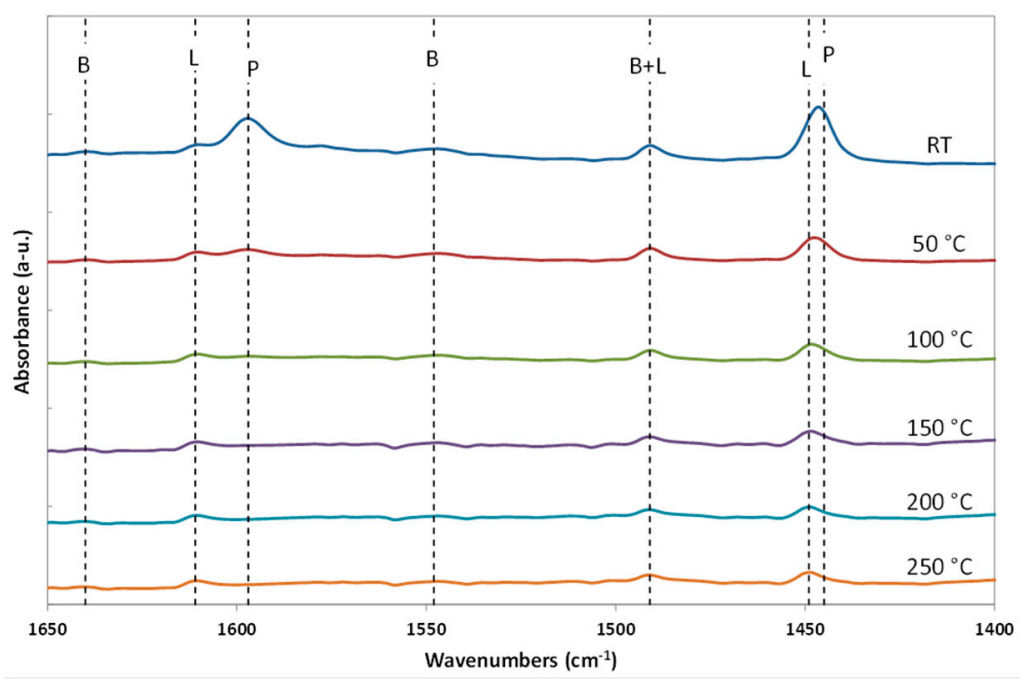

Figure 3. FT-IR pyridine adsorption and desorption spectra, recorded at different desorption temperatures for $\mathrm{NbO}_{\mathrm{x}}-\mathrm{SiO}_{2}$. Pyridine adsorption at room temperature. Desorption steps were performed from room temperature to $250^{\circ} \mathrm{C}$. L and B marks show the location of bands attributed to Lewis and Brønsted acid sites, respectively.

\subsection{Catalytic Performance in the Liquid-Phase Epoxidation Methyl Oleate}

The $\mathrm{NbO}_{x}-\mathrm{SiO}_{2}$ catalyst was first tested in the liquid-phase selective epoxidation of pure methyl oleate, which is the main component of karanja FAME mixture (Table 1).

No epoxides were observed throughout the reaction in the absence of the $\mathrm{NbO}_{x}-\mathrm{SiO}_{2}$ catalyst. A maximum conversion of $8-10 \%$ was recorded after $24 \mathrm{~h}$, due to the unselective production of 
undefined oxidised by-products linked to the action of hydrogen peroxide. However, no specific formation of epoxidised derivatives was detected.

$\mathrm{NbO}_{\mathrm{x}}-\mathrm{SiO}_{2}$ showed a promising performance in terms of conversion of methyl oleate (up to $75 \%$ ) and selectivity to the related epoxide, i.e., methyl epoxystearate (up to 82\%) (Figure 4). These data are consistent with those previously recorded over similar $\mathrm{Nb}(\mathrm{V})$ grafted over mesoporous silicates, with an ordered or non-ordered array of pores [40,41]. A direct comparison, under the same experimental conditions, was carried out here, by testing a benchmark catalyst, i.e., an ordered mesoporous $\mathrm{Nb}-\mathrm{MCM}-41$ catalyst, obtained by depositing niobocene dichloride under controlled atmosphere, with a comparable niobium content $(1.0 \mathrm{wt} . \% \mathrm{Nb})$ [31]. This catalyst is obtained via liquid-phase grafting of the organometallic precursor onto a high specific surface area MCM-41 support under anhydrous conditions in dry chloroform. Such synthesis procedure leads to evenly dispersed $\mathrm{Nb}(\mathrm{V})$ sites on the surface of MCM-41 (cf. DRS-UV-vis spectrum of Nb-MCM-41 in Figure S7) and to good performances in the epoxidation of unsaturated FAMEs, especially in terms of specific activity [41]. For these reasons, Nb-MCM-41 has been chosen here as a benchmark catalyst for this kind of comparison. In terms of conversion profile, $\mathrm{NbO}_{x}-\mathrm{SiO}_{2}$ was less active than $\mathrm{Nb}-\mathrm{MCM}-41$, especially in the initial hours of reaction, where the former showed a specific activity $40 \%$ lower than the latter $\left(32 \mathrm{~h}^{-1}\right.$ vs. $52 \mathrm{~h}^{-1}$, expressed as moles of converted $\mathrm{C}=\mathrm{C}$ bond per moles of $\mathrm{Nb}$ site per unit of time, under the conditions reported in Figure 4). Such difference in activity can be attributed to a better dispersion of the $\mathrm{Nb}(\mathrm{V})$ centres for $\mathrm{Nb}-\mathrm{MCM}-41$ than for $\mathrm{NbO}_{\mathrm{x}}-\mathrm{SiO}_{2}$, hence leading to a higher availability of catalytically active sites and higher specific activity. The difference between the two catalysts, however, was narrower at longer reaction times ( $89 \%$ vs. $75 \%$ of methyl oleate conversion, after $24 \mathrm{~h}$ ). On the contrary, in terms of selectivity to methyl epoxystearate, the two catalysts showed rather similar values. Such result suggests that, even if the $\mathrm{Nb}$ sites are deposited on silica supports with different morphologies, this feature does not affect the overall behavior of the catalyst, the main product being methyl epoxystearate. Taking into account that most of the activity was displayed by the catalyst in the first hours of reaction and that the increase in the conversion profile was far less marked in the remaining time, the following studies were carried out in a time range of $4 \mathrm{~h}$ maximum.

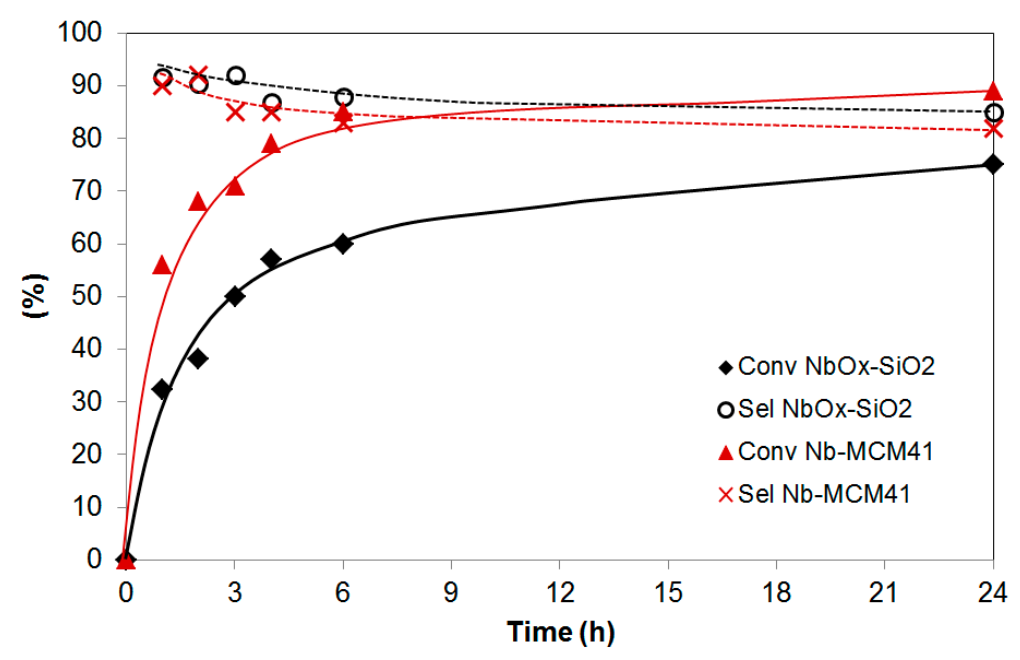

Figure 4. Conversion of methyl oleate, $\mathrm{MO}$ (solid lines) and selectivity to methyl epoxystearate (dashed lines) vs. time over $\mathrm{NbO}_{x}-\mathrm{SiO}_{2}$ (black symbols) and $\mathrm{Nb}-\mathrm{MCM}-41$ (red symbols). Reaction conditions: glass batch reactor, $100 \mathrm{mg}$ catalyst, $1 \mathrm{mmol} \mathrm{MO}, 4 \mathrm{mmol}$ aq. $\mathrm{H}_{2} \mathrm{O}_{2}, 90{ }^{\circ} \mathrm{C}, 300 \mathrm{rpm}, 5 \mathrm{~mL} \mathrm{CH} 3 \mathrm{CN}$.

The influence of the substrate to oxidant ratio on the catalytic performance was then considered (Figure 5). The best results were obtained at a methyl oleate to hydrogen peroxide ratio of 1:3. At molar ratios lower than 1:3, lower conversion and epoxide yield values were attained. For a 1:2 ratio, in fact, the oxidant became a limiting agent. This was confirmed by iodometric assays at the end of $4 \mathrm{~h}$ reaction, which revealed that virtually no oxidant was left in the final reaction mixture (no formation of brownish 
triiodide species was observed after addition of potassium iodide). On the contrary, for higher oxidant ratios (from 1:3 to 1:10), hydrogen peroxide was always in excess and the reaction was therefore not limited by the consumption of the oxidant. However, for very high amounts of $\mathrm{H}_{2} \mathrm{O}_{2}$, a gradual decrease in epoxide selectivity was observed, likely due to the concurrent, increasing formation of undesired oxidation by-products, obtained via free-radical reaction pathways. This led to lower final epoxide yields (Figure 5). For these reasons, a molar ratio of 1:3 was chosen for further studies.

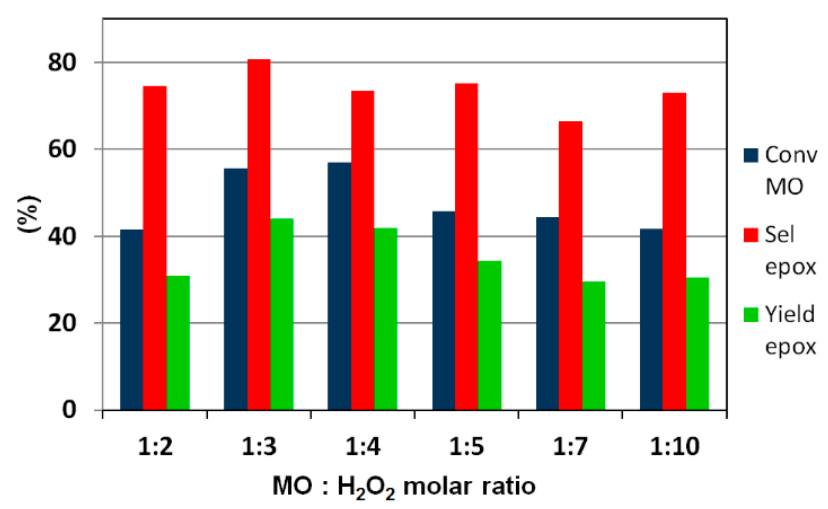

Figure 5. Influence of the alkene to $\mathrm{H}_{2} \mathrm{O}_{2}$ ratio on the epoxidation of pure methyl oleate (MO) over $\mathrm{NbO}_{\mathrm{x}}-\mathrm{SiO}_{2}$. Conditions: $100 \mathrm{mg}$ catalyst, $1 \mathrm{mmol} \mathrm{MO}$, aq. $\mathrm{H}_{2} \mathrm{O}_{2}, 90^{\circ} \mathrm{C}, 4 \mathrm{~h}, 300 \mathrm{rpm}, 5 \mathrm{~mL} \mathrm{CH} \mathrm{CN}$.

The influence of the catalyst loading, expressed with respect to the mass of the methyl oleate substrate present in the reaction mixture, on the catalytic performance was finally examined (Figure 6). The higher the amount of $\mathrm{NbO}_{x}-\mathrm{SiO}_{2}$ catalyst, the higher were the conversion of methyl oleate and the yield to methyl epoxystearate. In terms of turn-over numbers (expressed as moles of methyl oleate converted per moles of $\mathrm{Nb}$ present in the catalyst), somewhat constant values were obtained, spanning from 51 to 62 , the maximum TOF being recorded at $30 \%$ of catalyst loading. Nevertheless, a gradual worsening of the selectivity to epoxide was observed, at the same time, for higher catalyst loadings. Clearly, at higher conversion values, the formation of by-products, other than methyl epoxystearate was favored. For these reasons, a catalyst to methyl oleate mass ratio of $30 \%$ was chosen as a good compromise in terms of alkene conversion and selectivity to the desired epoxide.

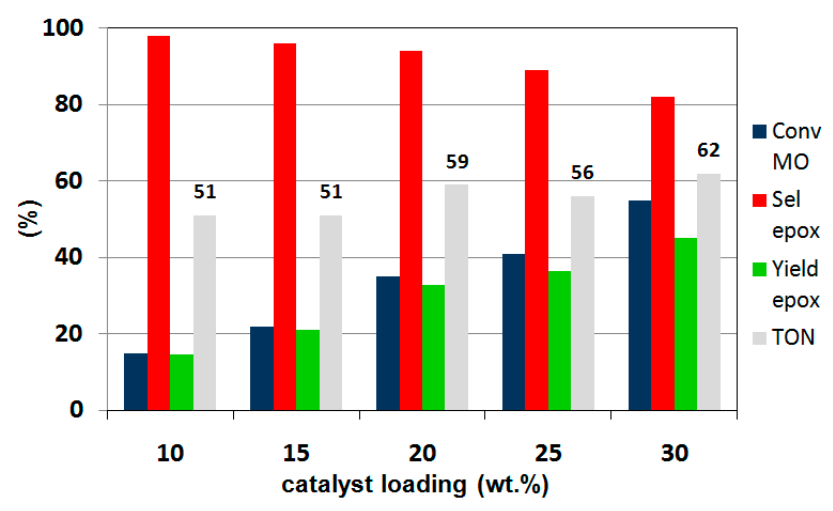

Figure 6. Influence of the mass of $\mathrm{NbO}_{x}-\mathrm{SiO}_{2}$ catalyst (expressed as wt.\% with respect to the mass of methyl oleate) on the epoxidation of pure methyl oleate (MO). Conditions: $1 \mathrm{mmol} \mathrm{MO}, 3 \mathrm{mmol}$ aq. $\mathrm{H}_{2} \mathrm{O}_{2}, 90^{\circ} \mathrm{C}, 4 \mathrm{~h}, 300 \mathrm{rpm}, 5 \mathrm{~mL} \mathrm{CH} \mathrm{CH}_{3} \mathrm{CN}$. TON values (turn-over numbers; gray bars) are expressed as moles of $\mathrm{MO}$ converted per moles of $\mathrm{Nb}$ in the catalyst (in $4 \mathrm{~h}$ ).

\subsection{Catalytic Performance in the Liquid-Phase Epoxidation Karanja Oil FAME Mixture}

Once the most suitable reaction conditions were defined, $\mathrm{NbO}_{x}-\mathrm{SiO}_{2}$ was then tested on the FAME mixture from karanja oil. The catalytic performance is reported in Figure 7, for $\mathrm{NbO}_{x}-\mathrm{SiO}_{2}$ and the 
reference catalyst $\mathrm{Nb}-\mathrm{MCM}-41$. Considering that karanja oil FAME contains a non-negligible fraction of diunsaturated fatty acids (ca. 18\% of C18:2; Table 1), an alkene to oxidant ratio of 1:4 was used in these tests, in order to assure a constant excess of hydrogen peroxide along the reaction.

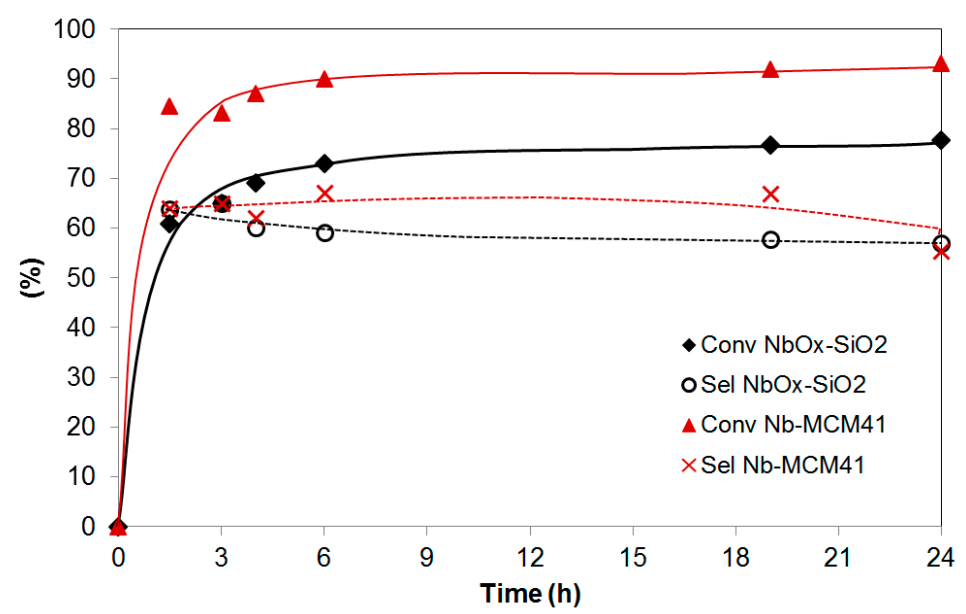

Figure 7. Conversion of $\mathrm{C}=\mathrm{C}$ double bonds of karanja FAME mixture (solid lines) and selectivity to monoepoxides (dashed lines) vs. time over $\mathrm{NbO}_{\mathrm{x}}-\mathrm{SiO}_{2}$ (black symbols) and $\mathrm{Nb}-\mathrm{MCM}-41$ (red symbols). Reaction conditions: glass batch reactor, $100 \mathrm{mg}$ catalyst, $1 \mathrm{mmol} \mathrm{C}=\mathrm{C}$ substrate, $4 \mathrm{mmol}$ aq. $\mathrm{H}_{2} \mathrm{O}_{2}$, $90{ }^{\circ} \mathrm{C}, 300 \mathrm{rpm}, 5 \mathrm{~mL} \mathrm{CH} 3 \mathrm{CN}$.

In this case too, $\mathrm{Nb}-\mathrm{MCM}-41$ proved to be more active than $\mathrm{NbO}_{\mathrm{x}}-\mathrm{SiO}_{2}$, in terms of conversion of the unsaturated FAMEs and specific activity $\left(53 \mathrm{~h}^{-1}\right.$ vs. $\left.42 \mathrm{~h}^{-1}\right)$. To our delight, very high conversion values (up to $70 \%$ for $\mathrm{NbO}_{x}-\mathrm{SiO}_{2}$ ) were already reached in the first $4 \mathrm{~h}$ of reaction, the advancement of the reaction in the following $20 \mathrm{~h}$ being very modest. In comparison with the values obtained with pure methyl oleate ( $c f$. Figure 4 vs. 7), lower selectivities and yields to the desired mixture of epoxidized FAMEs were observed here. In fact, a maximum yield in monoepoxides of $45 \%$ was recorded for $\mathrm{NbO}_{\mathrm{x}}-\mathrm{SiO}_{2}$ after $24 \mathrm{~h}$. The presence of diepoxy derivatives in the reaction mixture likely leads to the formation of larger molecular mass by-products, which appear in the chromatograms, especially after long reaction times, and can be attributed to a partial oligomerization of the oxidized primary products. These heavy compounds, poorly defined and characterized, overall give rise to lower selectivity values.

To our best knowledge, this work reports for the first time the use of a heterogeneous catalyst for the epoxidation of the FAMEs mixture derived from Millettia pinnata oil, without the use of UV irradiation or sacrificial reactants [18].

Finally, the possibility to recover and reuse the $\mathrm{NbO}_{x}-\mathrm{SiO}_{2}$ catalyst in three further catalytic cycles was investigated (Figure 8). It was necessary to thoroughly rinse the solid with fresh solvent and calcine it again at high temperature, to restore the pristine white color and thus to get rid of the possible heavy by-products stuck onto the catalyst surface.

A slight loss in FAME conversion (from $71 \%$, on the fresh catalyst, to $62 \%$, at the end of the third recycle step) was observed, whereas the selectivity to epoxide was virtually unchanged across the catalytic runs. This behavior shows that the catalyst is quite robust and can be reused, after an appropriate process of calcination and regeneration steps.

The modest decrease in catalytic activity might be attributed to the gradual deactivation of the catalytically active $\mathrm{Nb}(\mathrm{V})$ centers by fouling species that cannot be entirely removed by intermediate calcination. However, the elemental $\mathrm{C}, \mathrm{H}, \mathrm{N}$ analysis carried out on the spent catalyst, after rinsing with solvent, but before calcination, gave a low amount of residual organic species on the solid, namely, $0.38 \mathrm{wt} . \%$ and $0.04 \mathrm{wt} . \%$, for $\mathrm{C}$ and $\mathrm{N}$, respectively. The reason should be rather attributed to a gradual modification of the chemical environment of the $\mathrm{Nb}(\mathrm{V})$ sites, as shown by the $\mathrm{DR} U \mathrm{UV}$-vis spectrum of the recycled $\mathrm{NbO}_{x}-\mathrm{SiO}_{2}$ solid, after four catalytic cycles (see Figure 1c). Indeed, the used catalyst 
showed a marked broadening of the band up to $325-340 \mathrm{~nm}$ that is attributed to a gradual aggregation of niobium centers along the catalysis and regeneration steps, by high-temperature calcination.

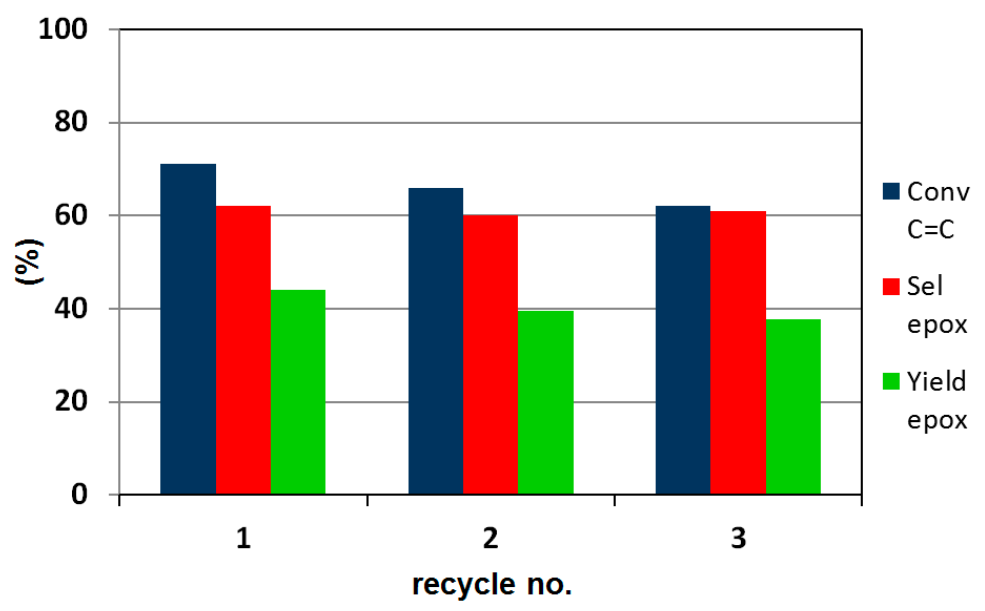

Figure 8. Catalytic performance of the recycled $\mathrm{NbO}_{x}-\mathrm{SiO}_{2}$ catalyst in the epoxidation of karanja FAME mixture over. Conditions: $200 \mathrm{mg}$ catalyst (at the 1 st catalytic run), $2 \mathrm{mmol} \mathrm{C}=\mathrm{C}$ substrate, 8 aq. $\mathrm{H}_{2} \mathrm{O}_{2}$, $90^{\circ} \mathrm{C}, 4 \mathrm{~h}, 300 \mathrm{rpm}, 10 \mathrm{~mL} \mathrm{CH} 3 \mathrm{CN}$.

A surface reorganization of $\mathrm{Nb}$ species occurred, with the formation of a remarkable amount of oligomeric metal sites in penta- or hexacoordinated geometry and a diminution of the catalytically active and available coordination sites at the $\mathrm{Nb}$ centers [56]. However, this phenomenon has little influence on the activity of the catalyst, as confirmed by the modest loss in activity observed at the end of the third recycling step.

Finally, the presence of soluble niobium species leached out from the catalyst was excluded by performing a heterogeneity ("hot filtration") test (Figure S8). The catalyst was removed from the warm reaction mixture by thorough centrifugation after $1 \mathrm{~h}$ and the resulting solution was checked for further reaction [57]. The reaction did not proceed and, in particular, no formation of new epoxidised compounds was recorded. No leaching of homogeneously-active species was thus revealed in liquid phase.

\section{Materials and Methods}

\subsection{Materials and Reactants}

$\mathrm{NH}_{4} \mathrm{Nb}\left(\mathrm{C}_{2} \mathrm{O}_{4}\right)_{2} \cdot \mathrm{H}_{2} \mathrm{O}$ was received from Companhia Brasileira de Metallurgia e Mineração, CBMM, and used without further pretreatment. Bulk hexagonal-phase $\mathrm{Nb}_{2} \mathrm{O}_{5}$ (Sigma-Aldrich, Milan, Italy 99.99\%) was used as reference for the catalytic comparison. A commercial mesoporous non-ordered silica gel (Fluka, Milan, Italy, code 60741, high purity grade, pore size $60 \AA$, 70-230 mesh, 63-200 $\mu \mathrm{m}$ ) was used as a support, without further pretreatment. D-(-)-fructose (Sigma-Aldrich, Milan, Italy $>99 \%$ ), ammonia (Fluka), bis(cyclopentadienyl)niobium(IV) dichloride (Aldrich, 95\%), sodium lumps (Carlo Erba, Milan, Italy, purum), methyl oleate (Sigma-Aldrich, Italy, 99\%), acetonitrile (Sigma-Aldrich, Italy, HPLC grade), methanol (Sigma-Aldrich, Italy, HPLC grade), aqueous hydrogen peroxide (Aldrich, $50 \%$ or $30 \%$ ) and mesitylene (Fluka, puriss., $99 \%$ ) were all purchased and used as received.

\subsection{Catalyst Preparation}

The $\mathrm{NbO}_{\mathrm{x}}-\mathrm{SiO}_{2}$ catalyst was prepared as follows: $0.5 \mathrm{~g}$ of $\mathrm{NH}_{4} \mathrm{Nb}\left(\mathrm{C}_{2} \mathrm{O}_{4}\right)_{2} \cdot \mathrm{H}_{2} \mathrm{O}$ and $1.5 \mathrm{~g}$ of fructose were dissolved in $20 \mathrm{~mL}$ of deionised water, then an aqueous solution of ammonia (28\%) was added dropwise until $\mathrm{pH}=9$ and $5.0 \mathrm{~g}$ of $\mathrm{SiO}_{2}$ were added. After $20 \mathrm{~min}$ under stirring, the slurry, held in an ice bath at $0{ }^{\circ} \mathrm{C}$, was diluted with $3 \mathrm{~L}$ of water. The solid was separated by filtration with a Büchner funnel, washed with water, dried overnight at $120^{\circ} \mathrm{C}$, and calcined in air at $350^{\circ} \mathrm{C}$ for $4 \mathrm{~h}$. 
One batch of reference $\mathrm{Nb}-\mathrm{MCM}-41$ catalyst ( $\mathrm{Nb}$ content $1.0 \mathrm{wt} . \%)$ was prepared via liquid-phase deposition of bis(cyclopentadienyl)niobium(IV) dichloride, $\mathrm{Cp}_{2} \mathrm{NbCl}_{2}$, onto a pure-silica MCM-41 support (specific surface area: $1079 \mathrm{~m}^{2} \mathrm{~g}^{-1}$ ), by adapting the synthesis procedure described in Ref. [58] for titanocene dichloride. In detail, the MCM-41 support was prepared according to the procedure described in previous literature [59]. Then, pure silica MCM-41 was heated in air at $500{ }^{\circ} \mathrm{C}$ for $1 \mathrm{~h}$ and then in vacuo at the same temperature for $6 \mathrm{~h} . \mathrm{Cp}_{2} \mathrm{NbCl}_{2}$ was dissolved in anhydrous $\mathrm{CHCl}_{3}$ under argon. The resulting solution was added to the dried MCM-41 and stirred for $30 \mathrm{~min}$ at room temperature. Freshly distilled triethylamine was then added to the suspension and left under stirring overnight. The solid was filtered on a Büchner funnel, washed with fresh $\mathrm{CHCl}_{3}$ and dried for $3 \mathrm{~h}$. It was calcined at $550{ }^{\circ} \mathrm{C}$ in flowing oxygen $\left(80 \mathrm{~mL} \mathrm{~min}^{-1}\right)$ for $6 \mathrm{~h}$.

\subsection{Preparation of Karanja Oil FAME Mixture}

In a $1 \mathrm{~L}$, two-necked, flame-dried flask equipped with a magnetic stirrer, a dropping funnel and an Allihn condenser with a flow control adapter on the top, anhydrous methanol (500 $\mathrm{mL}$ ) was stirred under a gentle stream of anhydrous nitrogen, while sodium in small pieces was added. After complete dissolution of the solid, karanja oil $(200 \mathrm{~mL}$ ) was added drop-wise (in $10 \mathrm{~min}$ ). The resulting two-phases mixture, which became homogeneous after about $10 \mathrm{~min}$, was then heated at reflux (oil bath $75{ }^{\circ} \mathrm{C}$ ) under stirring for $2.5 \mathrm{~h}$. The mixture was then cooled to $35-40{ }^{\circ} \mathrm{C}$, transferred into a $1 \mathrm{~L}$ one-necked flask and the solvent distilled under reduced pressure (rotary evaporator, $40^{\circ} \mathrm{C}$ ). After cooling at $5-10^{\circ} \mathrm{C}$, the crude was quenched with water $(200 \mathrm{~mL})$, acidified to $\mathrm{pH} 6$ with glacial acetic acid and extracted with petroleum ether (40-60 fraction, $3 \times 200 \mathrm{~mL}$ ). The combined organic layers were then washed with brine $(2 \times 100 \mathrm{~mL})$, dried over anhydrous $\mathrm{Na}_{2} \mathrm{SO}_{4}$ and filtered. Petroleum ether was removed by rotary evaporator and, finally, vacuum pump ( $2 \mathrm{~h}$ at 0.01 Torr). The resulting light-brown oil (174 g) was distilled under vacuum using an oil diffusive pump, obtaining three distillation fractions. The fraction $152-153^{\circ} \mathrm{C} / 0.08$ Torr was used for the catalytic tests.

\subsection{Characterization of Karanja Oil FAME Mixture}

The karanja FAME mixture was characterized by ${ }^{1} \mathrm{H}$ - and ${ }^{13} \mathrm{C}$-NMR spectrophotometry at room temperature (Bruker UXNMR, $400 \mathrm{MHz}$ ). Iodine value was computed from ${ }^{1} \mathrm{H}-\mathrm{NMR}$ spectra of the mixture, as described in Ref. [60].

\subsection{Catalyst Characterization}

Diffuse reflectance UV-Vis, DR UV-Vis, spectra of the powder oxidic materials were recorded in the range from 200 to $500 \mathrm{~nm}$ on a Praying-Mantis Diffuse Reflectance Accessory (Harrick Sci, UK) installed on an Evolution 600 spectrophotometer (Thermo). A Spectralon ${ }^{\circledR}$ disc was used as a reference material for calibration background measurement. Spectra were recorded under air, at room temperature, on samples previously calcined at $500{ }^{\circ} \mathrm{C}$ under dry air and cooled down to room temperature under dynamic vacuum.

Transmission electron microscopy (TEM) analysis was carried out by a ZEISS LIBRA 200FE microscope equipped with a $200 \mathrm{kV}$ FEG source. Energy-dispersive X-ray spectra (EDS, Oxford, UK INCA Energy TEM 200) and elemental maps were collected along with HAADF-STEM (high angular annular dark field scanning transmission electron microscopy) images. The specimen was finely smashed in an agate mortar, suspended in isopropanol and sonicated, then the suspension was dropped onto a holey carbon-coated copper grid (300 mesh) and the solvent was evaporated.

FT-IR studies by pyridine adsorption and desorption were carried out on an FTS-60 spectrophotometer equipped with a mid-IR MCT detector (BioRad, Segrate, Italy). The experiments were performed on sample disks $(8-15 \mathrm{mg})$ after a simple dehydration treatment $\left(270^{\circ} \mathrm{C}, 20 \mathrm{~min}\right.$ dry air +20 min under vacuum). One spectrum was collected before probe molecule adsorption, as a blank experiment. Then, pyridine (Py) adsorption was carried out at room temperature and the following 
desorption steps were run from room temperature to $250{ }^{\circ} \mathrm{C}$. The spectrum of each desorption step was acquired every $50^{\circ} \mathrm{C}$, after cooling the sample.

\subsection{Liquid-Phase Epoxidation Tests of Methyl Oleate and Karanja FAME Mixture}

The niobium-silica catalysts $(100 \mathrm{mg})$ were pretreated under anhydrous air at $500{ }^{\circ} \mathrm{C}$ and cooled to room temperature in vacuo prior to use. The epoxidation tests were carried out using methyl oleate and karanja FAME mixture ( $1 \mathrm{mmol}$ of $\mathrm{C}=\mathrm{C}$ unsaturations), in a round-bottom glass batch reactor, in an oil bath at $90^{\circ} \mathrm{C}$ equipped with magnetic stirring (ca. $800 \mathrm{rpm}$ ) under dry nitrogen atmosphere. Acetonitrile, aqueous hydrogen peroxide $\left(\mathrm{H}_{2} \mathrm{O}_{2} ;\right.$ aq. $\left.50 \%\right)$ and mesitylene were used as solvent, oxidant and internal standard, respectively. $\mathrm{H}_{2} \mathrm{O}_{2}$ was added with a $\mathrm{C}=\mathrm{C}$ substrate to oxidant molar ratio spanning from 1:2 to 1:10. The final volume of the reaction mixture was $5 \mathrm{~mL}$. Samples were taken at regular intervals and analysed by gas-chromatography (Agilent 6890 Series; HP- 5 column, $30 \mathrm{~m} \times 0.25 \mathrm{~mm} \times 0.25 \mu \mathrm{m}$; FID detector). Chromatographic peaks were identified by comparison with genuine reference standards and/or by means of GC-MS analysis. Main epoxidised products were: methyl epoxystearate (methyl cis-9,10-epoxyoctadecanoate), methyl epoxyoleate (methyl cis-9,10(12,13)-epoxyoctadec-12(9)-enoate) and methyl diepoxystearate (methyl cis-9,10-12,13-epoxyoctadecanoate), obtained through epoxidation of methyl oleate, one unsaturation of methyl linoleate and two unsaturations of methyl linoleate, respectively.

In the tests for the recovery of the catalyst, the solid was separated by filtration, washed with clean methanol, dried at $110^{\circ} \mathrm{C}$, calcined again at $500{ }^{\circ} \mathrm{C}$ under dry air and then used in a new test as described above. After all tests, the presence of residual hydrogen peroxide was checked and confirmed by iodometric assays and titrations.

\section{Conclusions}

Three main results were achieved during the present study:

(1) a conceptually simple, novel niobium-silica catalyst was prepared starting from cheap and easily available precursors and following a synthesis protocol that does not require the use of controlled atmosphere or organic solvents;

(2) the $\mathrm{NbO}_{x}-\mathrm{SiO}_{2}$ catalyst was active in the catalytic epoxidation of unsaturated fatty acid methyl esters in the presence of aqueous hydrogen peroxide, showing a good robustness to repeated recovery and reuse cycles; and

(3) a solid catalyst was successfully used, for the first time here, in the epoxidation of a mixture of FAMEs directly derived from a real sample of karanja (Millettia pinnata) seed oil, without the need of additional co-reactants or promoters.

The deposition of the precursor niobium species in aqueous phase is therefore a viable approach that can be straightforwardly applied in those working environments where it is not possible to follow synthesis protocols based on sensitive, expensive and/or hazardous reagents. This work was, in addition, an opportunity to put a special emphasis on the growing importance of non-edible vegetable oils as valuable building blocks for biomass-based intermediate chemicals.

Supplementary Materials: The following are available online at http://www.mdpi.com/2073-4344/9/4/344/s1. Figure S1: ${ }^{1} \mathrm{H}-\mathrm{NMR}$ spectrum of karanja FAME mixture; Figure S2: ${ }^{13} \mathrm{C}-\left\{{ }^{1} \mathrm{H}\right\}-\mathrm{NMR}$ spectrum of karanja FAME mixture; Figure S3: X-ray diffraction patterns of $\mathrm{NbO}_{x}-\mathrm{SiO}_{2}$ catalyst; Figure S4: Representative TEM micrographs of $\mathrm{NbO}_{\mathrm{x}}-\mathrm{SiO}_{2}$; Figure S5: EDS spectrum for $\mathrm{NbO}_{\mathrm{x}}-\mathrm{SiO}_{2}$; Figure $\mathrm{S6}$ : $\mathrm{BJH}$ pore distribution for $\mathrm{SiO}_{2}$ and $\mathrm{NbO}_{\mathrm{x}}-\mathrm{SiO}_{2}$; Figure S7: DRS UV-vis pattern of a reference $\mathrm{Nb}-\mathrm{MCM}-41$ catalyst ( $\mathrm{Nb}$ content $1.0 \mathrm{wt} . \%$ ) prepared via liquid-phase deposition of bis(cyclopentadienyl)niobium(IV) dichloride over pure-silica MCM-41 under dry air; Figure S8: Conversion of $\mathrm{C}=\mathrm{C}$ double bonds of karanja FAME mixture (solid lines) and selectivity to monoepoxides (dashed line) vs. time over $\mathrm{NbO}_{\mathrm{x}}-\mathrm{SiO}_{2}$.

Author Contributions: Conceptualization, M.G. and V.V.B.; catalyst preparation, DRS-UV-vis investigation, FT-IR analysis N.S.; benchmark catalyst preparation, M.G.; high-resolution microscopy investigation, C.E.; karanja FAME preparation and characterization, M.P.; XRD analysis, catalytic testing on MO and karanja FAME, P.S.N., V.V.B.; writing and editing supervision, M.G., N.R. and R.P.; funding acquisition, V.V.B. and M.G. 
Funding: ISTM and NCL gratefully acknowledge the CNR, Italy—CSIR, India Bilateral Programme "Development of Catalytic Renewable Process by Converting Indian Origin Non-Edible Oil to Valuable Chemicals" for partial financial support.

Acknowledgments: ISTM is grateful to Companhia Brasileira de Metallurgia e Mineração, CBMM, for providing a sample of $\mathrm{NH}_{4} \mathrm{Nb}\left(\mathrm{C}_{2} \mathrm{O}_{4}\right)_{2} \cdot \mathrm{H}_{2} \mathrm{O}$.

Conflicts of Interest: The authors declare no conflict of interest.

\section{References}

1. Guidotti, M.; Palumbo, C. Catalytic Epoxidation of Organics from Vegetable Sources. In Encyclopaedia of Inorganic and Bioinorganic Chemistry; Atwood, D.A., Ed.; Wiley: Chichester, UK, 2016; pp. 373-385.

2. Chowdhury, A.; Anthony, P. A Review on Biodegradable Polymeric Materials Derived from Vegetable Oils for Diverse Applications. Int. J. Sci. Res. 2016, 5, 1786-1791.

3. Noor Armylisas, A.H.; Siti Hazirah, M.F.; Yeong, S.K.; Hazimah, A.H. Modification of olefinic double bonds of unsaturated fatty acids and other vegetable oil derivatives via epoxidation: A review. Grasas Aceites 2017, 68, e174. [CrossRef]

4. Borugadda, V.B.; Goud, V.V. Epoxidation of Castor Oil Fatty Acid Methyl Esters (COFAME) as a Lubricant base Stock Using Heterogeneous Ion-exchange Resin (IR-120) as a Catalyst. Energy Procedia 2014, 54, 75-84. [CrossRef]

5. Moser, B.R.; Sharma, B.K.; Doll, K.M.; Erhan, S.Z. Diesters from Oleic Acid: Synthesis, Low Temperature Properties, and Oxidation Stability. J. Am. Oil Chem. Soc. 2007, 84, 675-680. [CrossRef]

6. Doll, K.M.; Erhan, S.Z. Synthesis of cyclic acetals (ketals) from oleochemicals using a solvent free method. Green Chem. 2008, 10, 712-717. [CrossRef]

7. Kandula, S.; Stolp, L.; Grass, M.; Woldt, B.; Kodali, D. Synthesis and Functional Evaluation of Soy Fatty Acid Methyl Ester Ketals as Bioplasticizers. J. Am. Oil Chem. Soc. 2014, 91, 1967-1974. [CrossRef]

8. Zhang, G.; Kodani, S.; Hammock, B.D. Stabilized epoxygenated fatty acids regulate inflammation, pain, angiogenesis and cancer. Prog. Lipid Res. 2014, 53, 108-123. [CrossRef]

9. Stern, A.; Guidotti, M.; Shaubi, E.; Popov, M.; Linder, C.; Heldman, E.; Grinberg, S. Steric environment around acetylcholine head groups of bolaamphiphilic nanovesicles influences the release rate of encapsulated compounds. Int. J. Nanomed. 2014, 9, 561-574.

10. Mardhiah, H.H.; Ong, H.C.; Masjuki, H.H.; Lim, S.; Lee, H.V. A review on latest developments and future prospects of heterogeneous catalyst in biodiesel production from non-edible oils. Renew. Sustain. Energy Rev. 2017, 67, 1225-1236. [CrossRef]

11. Fritsch, C.; Staebler, A.; Happel, A.; Cubero Márquez, M.A.; Aguiló-Aguayo, I.; Abadias, M.; Gallur, M.; Cigognini, I.M.; Montanari, A.; López, M.J.; et al. Processing, Valorization and Application of Bio-Waste Derived Compounds from Potato, Tomato, Olive and Cereals: A Review. Sustainability 2017, 9, 1492. [CrossRef]

12. Banković-Ilić, I.B.; Stojković, I.J.; Stamenković, O.S.; Veljkovic, V.B.; Hung, Y.T. Waste animal fats as feedstocks for biodiesel production. Renew. Sustain. Energy Rev. 2014, 32, 238-254. [CrossRef]

13. Muthukumaran, C.; Praniesh, R.; Navamani, P.; Swathi, R.; Sharmila, R.; Manoj Kumar, N. Process optimization and kinetic modeling of biodiesel production using non-edible Madhuca indica oil. Fuel 2017, 195, 217-225. [CrossRef]

14. Patel, R.L.; Sankhavara, C.D. Biodiesel production from Karanja oil and its use in diesel engine: A review. Renew. Sustain. Energy Rev. 2017, 71, 464-474. [CrossRef]

15. Bajwa, A.S.; Sathaye, S.; Kulkarni, V.M.; Patwardhan, A.V. Chemoenzymatic epoxidation of Karanja oil: An alternative to chemical epoxidation? Asia-Pac. J. Chem. Eng. 2016, 11, 314-322. [CrossRef]

16. Goud, V.V.; Pradhan, N.C.; Patwardhan, A.V. Epoxidation of Karanja (Pongamia glabra) oil by $\mathrm{H}_{2} \mathrm{O}_{2}$. J. Am. Oil Chem. Soc. 2006, 83, 635-640. [CrossRef]

17. Goud, V.V.; Patwardhan, A.V.; Dinda, S.; Pradhan, N.C. Epoxidation of karanja (Pongamia glabra) oil catalysed by acidic ion exchange resin. Eur. J. Lipid Sci. Technol. 2007, 109, 575-584. [CrossRef]

18. Kumar, D.; Ali, A. Ti/SiO 2 as a Nanosized Solid Catalyst for the Epoxidation of Fatty Acid Methyl Esters and Triglycerides. Energy Fuels 2012, 26, 2953-2961. [CrossRef] 
19. Kadam, A.; Pawar, M.; Yemul, O.; Thamke, V.; Kodam, K. Biodegradable biobased epoxy resin from karanja oil. Polymer 2015, 72, 82-92. [CrossRef]

20. Gaikwad, M.S.; Gite, V.V.; Mahulikar, P.P.; Hundiwale, D.G.; Yemul, O.S. Eco-friendly polyurethane coatings from cottonseed and karanja oil. Prog. Org. Coatings 2015, 86, 164-172. [CrossRef]

21. Sharmin, E.; Ashraf, S.M.; Ahmad, S. Synthesis, characterization, antibacterial and corrosion protective properties of epoxies, epoxy-polyols and epoxy-polyurethane coatings from linseed and Pongamia glabra seed oils. Int. J. Biol. Macromol. 2007, 40, 407-422. [CrossRef]

22. Bora, M.M.; Deka, R.; Ahmed, N.; Kakati, D.K. Karanja (Millettia pinnata (L.) Panigrahi) seed oil as a renewable raw material for the synthesis of alkyd resin. Ind. Crops Prod. 2014, 61, 106-114. [CrossRef]

23. Korlipara, V.P.; Mallampalli, S.L.K.; Krishnasamy, S.; Rachapudi, B.N.P. Process for the Preparation of Karanja Oil-Based Epoxy and Acyloxy Compounds as Lubricant Basestocks. Patent WO 2014009972, 16 January 2014.

24. Mustapha, R.; Razak Rahmat, A.; Abdul Majid, R.; Noor Hidayah Mustapha, S. Vegetable oil-based epoxy resins and their composites with bio-based hardener: A short review. Polym. Plastics Technol. Mater. 2019. [CrossRef]

25. Fraile, J.M.; Garcia, J.I.; Mayoral, J.A.; Vispe, E. Optimization of cyclohexene epoxidation with dilute hydrogen peroxide and silica-supported titanium catalysts. Appl. Catal. A: Gen. 2003, 245, 363-376. [CrossRef]

26. Gianotti, E.; Bisio, C.; Marchese, L.; Guidotti, M.; Ravasio, N.; Psaro, R.; Coluccia, S. Ti(IV) catalytic centers grafted on different siliceous materials: A spectroscopic and catalytic study. J. Phys. Chem. C 2007, 111, 5083-5089. [CrossRef]

27. Gallo, A.; Tiozzo, C.; Psaro, R.; Carniato, F.; Guidotti, M. Niobium metallocenes deposited onto mesoporous silica via dry impregnation as catalysts for selective epoxidation of alkenes. J. Catal. 2013, 298, 77-83. [CrossRef]

28. Kholdeeva, O.A.; Ivanchikova, I.D.; Maksimchuk, N.V.; Skobelev, I.Y. $\mathrm{H}_{2} \mathrm{O}_{2}$-based selective epoxidations: $\mathrm{Nb}$-silicates versus Ti-silicates. Catal. Today 2018. [CrossRef]

29. Aronne, A.; Turco, M.; Bagnasco, G.; Ramis, G.; Santacesaria, E.; Di Serio, M.; Marenna, E.; Bevilacqua, M.; Cammarano, C.; Fanelli, E. Gel derived niobium-silicon mixed oxides: Characterization and catalytic activity for cyclooctene epoxidation. Appl. Catal. A Gen. 2008, 347, 179-185. [CrossRef]

30. Tiozzo, C.; Palumbo, C.; Psaro, R.; Bisio, C.; Carniato, F.; Gervasini, A.; Carniti, P.; Guidotti, M. The stability of niobium-silica catalysts in repeated liquid-phase epoxidation tests: A comparative evaluation of in-framework and grafted mixed oxides. Inorg. Chim. Acta 2015, 431, 190-196. [CrossRef]

31. Tiozzo, C.; Bisio, C.; Carniato, F.; Gallo, A.; Scott, S.L.; Psaro, R.; Guidotti, M. Niobium-silica catalysts for the selective epoxidation of cyclic alkenes: The generation of the active site by grafting niobocene dichloride. Phys. Chem. Chem. Phys. 2013, 15, 13354-13362. [CrossRef]

32. Thornburg, N.E.; Nauert, S.L.; Thompson, A.B.; Notestein, J.M. Synthesis-structure-function relationships of silica-supported niobium(V) catalysts for alkene epoxidation with $\mathrm{H}_{2} \mathrm{O}_{2}$. ACS Catal. 2016, 6, 6124-6134. [CrossRef]

33. Ivanchikova, I.D.; Maksimchuk, N.V.; Skobelev, I.Y.; Kholdeeva, O.A. Mesoporous niobium-silicates prepared by evaporation-induced self-assembly as catalysts for selective oxidations with aqueous $\mathrm{H}_{2} \mathrm{O}_{2}$. J. Catal. 2015, 332, 138-148. [CrossRef]

34. Padula, I.D.; Chagas, P.; Furst, C.G.; Oliveira, L.C.A. Mesoporous Niobium Oxyhydroxide Catalysts for Cyclohexene Epoxidation Reactions. Appl. Sci. 2018, 8, 881. [CrossRef]

35. Paraguassú Cecchi, C.M.; Cesarín-Sobrinho, D.; Buarque Ferreira, A.B.; Netto-Ferreira, J.C. New Insights on the Oxidation of Unsaturated Fatty Acid Methyl Esters Catalyzed by Niobium(V) Oxide. A Study of the Catalyst Surface Reactivity. Catalysts 2018, 8, 6. [CrossRef]

36. Nowak, I. Frontiers in mesoporous molecular sieves containing niobium: From model materials to catalysts. Catal. Today 2012, 192, 80-88. [CrossRef]

37. Yan, W.; Ramanathan, A.; Ghanta, M.; Subramaniam, B. Towards highly selective ethylene epoxidation catalysts using hydrogen peroxide and tungsten- or niobium-incorporated mesoporous silicate (KIT-6). Catal. Sci. Technol. 2014, 4, 4433-4439. [CrossRef]

38. Yan, W.; Zhang, G.; Yan, H.; Liu, Y.; Chen, X.; Feng, X.; Jin, X.; Yang, C. Liquid-Phase Epoxidation of Light Olefins over $\mathrm{W}$ and $\mathrm{Nb}$ Nanocatalysts. ACS Sustain. Chem. Eng. 2018, 6, 4423-4452. [CrossRef]

39. Feliczak, A.; Walczak, K.; Wawrzyńczak, A.; Nowak, I. The use of mesoporous molecular sieves containing niobium for the synthesis of vegetable oil-based products. Catal. Today 2009, 140, 23-29. [CrossRef] 
40. Di Serio, M.; Turco, R.; Pernice, P.; Aronne, A.; Sannino, F.; Santacesaria, E. Valuation of $\mathrm{Nb}_{2} \mathrm{O}_{5}-\mathrm{SiO}_{2}$ catalysts in soybean oil epoxidation. Catal. Today 2012, 192, 112-116. [CrossRef]

41. Dworakowska, S.; Tiozzo, C.; Niemczyk-Wrzeszcz, M.; Michorczyk, P.; Ravasio, P.; Psaro, R.; Bogdał, D.; Guidotti, M. Mesoporous molecular sieves containing niobium $(\mathrm{V})$ as catalysts for the epoxidation of fatty acid methyl esters and rapeseed oil. J. Clean. Prod. 2017, 166, 901-909. [CrossRef]

42. Danov, S.M.; Kazantsev, O.A.; Esipovich, A.L.; Belousov, A.S.; Rogozhin, A.E.; Kanakov, E.A. Recent advances in the field of selective epoxidation of vegetable oils and their derivatives: A review and perspective. Catal. Sci. Technol. 2017, 7, 3659-3675. [CrossRef]

43. Turco, R.; Vitiello, R.; Tesser, R.; Vergara, A.; Andini, S.; Di Serio, M. Niobium Based Catalysts for Methyl Oleate Epoxidation Reaction. Topics Catal. 2017, 60, 1054-1061. [CrossRef]

44. Zaccheria, F.; Scotti, N.; Marelli, M.; Psaro, R.; Ravasio, N. Unravelling the properties of supported copper oxide: Can the particle size induce acidic behaviour? Dalton Trans. 2013, 42, 1319-1328. [CrossRef] [PubMed]

45. Guidotti, M.; Ravasio, N.; Psaro, R.; Gianotti, E.; Coluccia, S.; Marchese, L. Epoxidation of unsaturated FAMEs obtained from vegetable source over Ti(IV)-grafted silica catalysts: A comparison between ordered and non-ordered mesoporous materials. J. Mol. Catal. A Chem. 2006, 250, 218-225. [CrossRef]

46. Kumar Karmee, S.; Chadha, A. Preparation of biodiesel from crude oil of Pongamia pinnata. Biores. Technol. 2005, 96, 1425-1429. [CrossRef]

47. Pandey, A. Handbook of Plant-Based Biofuels; CRC Press: Boca Raton, FL, USA, 2008; pp. 255-266.

48. Branca, M.; Micera, G.; Dessì, A.; Sanna, D. Oxovanadium(IV) complex formation by simple sugars in aqueous solution. J. Inorg. Biochem. 1992, 45, 169-177. [CrossRef]

49. Baran, E.J. Oxovanadium(IV) complexes of carbohydrates: A brief overview. J. Inorg. Biochem. 2009, 103, 547-553. [CrossRef]

50. Thornburg, N.E.; Notestein, J.M. Rate and Selectivity Control in Thioether and Alkene Oxidation with $\mathrm{H}_{2} \mathrm{O}_{2}$ over Phosphonate-Modified Niobium(V)-Silica Catalysts. ChemCatChem 2017, 9, 3714-3724. [CrossRef]

51. Gao, X.; Wachs, I.E.; Wong, M.S.; Ying, J.Y. Structural and reactivity properties of Nb-MCM-41: Comparison with that of highly dispersed $\mathrm{Nb}_{2} \mathrm{O}_{5} / \mathrm{SiO}_{2}$ catalysts. J. Catal. 2001, 203, 18-24. [CrossRef]

52. Zhu, H.; Zheng, Z.; Gao, X.; Huang, Y.; Yan, Z.; Zou, J.; Yin, H.; Zou, Q.; Kable, S.H.; Zhao, J.; et al. Structural Evolution in a Hydrothermal Reaction between $\mathrm{Nb}_{2} \mathrm{O}_{5}$ and $\mathrm{NaOH}$ Solution: From $\mathrm{Nb}_{2} \mathrm{O}_{5}$ Grains to Microporous $\mathrm{Na}_{2} \mathrm{Nb}_{2} \mathrm{O}_{6} \cdot 2 / 3 \mathrm{H}_{2} \mathrm{O}$ Fibers and $\mathrm{NaNbO}_{3}$ Cubes. J. Am. Chem. Soc. 2006, 128, 2373-2384. [CrossRef]

53. Braga, V.S.; Dias, J.A.; Dias, S.C.L.; de Macedo, J.L. Catalyst Materials Based on $\mathrm{Nb}_{2} \mathrm{O}_{5}$ Supported on $\mathrm{SiO}_{2}-\mathrm{Al}_{2} \mathrm{O}_{3}$ : Preparation and Structural Characterization. Chem. Mater. 2005, 17, 690-695. [CrossRef]

54. Wawrzynczak, A.; Nowak, I.; Feliczak-Guzik, A. Toward Exploiting the Behavior of Niobium-Containing Mesoporous Silicates vs. Polyoxometalates in Catalysis. Front. Chem. 2018, 6, 560. [CrossRef] [PubMed]

55. Bregante, D.T.; Flaherty, D.W. Periodic Trends in Olefin Epoxidation over Group IV and V Framework-Substituted Zeolite Catalysts: A Kinetic and Spectroscopic Study. J. Am. Chem. Soc. 2017, 139, 6888-6898. [CrossRef] [PubMed]

56. Carniti, P.; Gervasini, A.; Marzo, M. Dispersed $\mathrm{NbO}_{\mathrm{x}}$ catalytic phases in silica matrixes: Influence of niobium concentration and preparative route. J. Phys. Chem. C. 2008, 112, 14064-14074. [CrossRef]

57. Guidotti, M.; Lazaro, B. Deactivation of molecular sieves in the synthesis of organic chemicals. In Deactivation and Regeneration of Zeolite Catalysts; Guisnet, M., Ramoa-Ribeiro, F., Eds.; Imperial College Press: London, UK, 2011; pp. 303-334.

58. Guidotti, M.; Conti, L.; Fusi, A.; Ravasio, N.; Psaro, R. Diastereoselective epoxidation of hydroxy-containing unsaturated terpenes on heterogeneous titanium-catalyst. J. Mol. Catal. A Chem. 2002, 182, 151-156. [CrossRef]

59. Kresge, C.T.; Leonowicz, M.E.; Roth, W.J.; Vartuli, J.C.; Beck, J.S. Ordered mesoporous molecular sieves synthesized by a liquid-crystal template mechanism. Nature 1992, 359, 710-712. [CrossRef]

60. Kumar, R.; Bansal, V.; Patel, M.B.; Sarpal, A.S. ${ }^{1}$ H Nuclear Magnetic Resonance (NMR) Determination of the Iodine Value in Biodiesel Produced from Algal and Vegetable Oils. Energy Fuels 2012, 26, 7005-7008. [CrossRef]

(C) 2019 by the authors. Licensee MDPI, Basel, Switzerland. This article is an open access article distributed under the terms and conditions of the Creative Commons Attribution (CC BY) license (http://creativecommons.org/licenses/by/4.0/). 